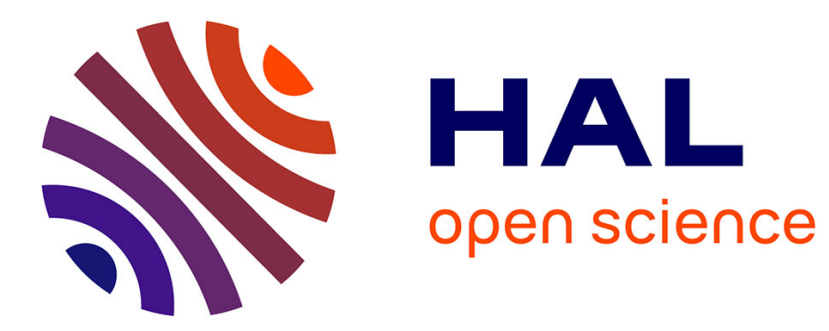

\title{
Peroxidase changes in Phoenix dactylifera palms inoculated with mycorrhizal and biocontrol fungi
}

Laaziza Ben Khaled, Manuela Pérez-Gilabert, Beatriz Dreyer, Abdallah Oihabi, Mario Honrubia, Asunción Morte

\section{- To cite this version:}

Laaziza Ben Khaled, Manuela Pérez-Gilabert, Beatriz Dreyer, Abdallah Oihabi, Mario Honrubia, et al.. Peroxidase changes in Phoenix dactylifera palms inoculated with mycorrhizal and biocontrol fungi. Agronomy for Sustainable Development, 2008, 28 (3), pp.411-418. hal-00886385

\section{HAL Id: hal-00886385 https://hal.science/hal-00886385}

Submitted on 1 Jan 2008

HAL is a multi-disciplinary open access archive for the deposit and dissemination of scientific research documents, whether they are published or not. The documents may come from teaching and research institutions in France or abroad, or from public or private research centers.
L'archive ouverte pluridisciplinaire HAL, est destinée au dépôt et à la diffusion de documents scientifiques de niveau recherche, publiés ou non, émanant des établissements d'enseignement et de recherche français ou étrangers, des laboratoires publics ou privés. 


\title{
Peroxidase changes in Phoenix dactylifera palms inoculated with mycorrhizal and biocontrol fungi
}

\author{
Laaziza Ben KHAlED $^{1,3 *}$, Manuela PÉreZ-GILABERT ${ }^{2}$, Beatriz DreYer ${ }^{1}$, Abdallah OIHABI $^{3}$, Mario HonRUBIA ${ }^{1}$, \\ Asunción MORTE ${ }^{1}$ \\ ${ }^{1}$ Laboratorio de Micología, Dept. Biología Vegetal (Botánica), Facultad de Biología, Universidad de Murcia, 30100 Murcia, Spain \\ ${ }^{2}$ Dept. Bioquímica y Biología Molecular A, Facultad de Biología, Universidad de Murcia, 30100 Campus de Espinardo, Murcia, Spain \\ ${ }^{3}$ Laboratoire de Physiologie Végétale, BP 2390, Faculté des Sciences-Semlalia, Marrakech, Morocco
}

(Accepted 26 March 2008)

\begin{abstract}
In Morocco, yields of date palms are highly decreased by the pathogen fungi Fusarium oxysporum. To solve this issue, mycorrhizal fungi and biocontrol agents could enhance plant resistance to pathogens. Here, we studied peroxidases in roots and leaves of Phoenix dactylifera in response to inoculation with the fungi Glomus mosseae and Trichoderma harzianum. Date palm plants were harvested 57 weeks after inoculation with mycorrhizal fungi and biocontrol fungi. We measured the dry biomass, arbuscular colonization, cytochemistry of peroxidase, and peroxidase forms and activities in roots and leaves. Our results show that mycorrhization increased the plant dry biomass by about $57 \%$. The rate of mycorrhizal colonization ranged from $25 \%$ to $30 \%$. Peroxidase activity in roots colonized by T. harzianum alone was 1.6 times higher than in control plants. Peroxidase activity in roots colonized by G. mosseae and T. harzianum was about 2 times higher than in control plants. Peroxidase activity in leaves increased by $+419 \%$ when plants were inoculated by both fungi. The cytochemical results show an accumulation of structural substances in root cell walls after inoculation with $T$. harzianum. These structural substances may increase the mechanical strength of the host cell walls in order to inhibit pathogen invasion. Peroxidase activities were found in plant cell walls; the tonoplast and host plasmalemma in the chloroplast; mitochondrial membranes; and intercellular spaces of plants inoculated with G. mosseae and T. harzianum. SDS-PAGE analyses of leaf extracts gave a main band at $54 \mathrm{kDa}$ for all the treatments. The stimulatory effect of Trichoderma on the peroxidase activity is a resistance mechanism of date plants to pathogens. The use of Trichoderma could thus be an alternative to chemicals in crop protection.
\end{abstract}

Peroxidase / Trichoderma / date palm / arbuscular mycorrhizal

\section{INTRODUCTION}

Phoenix dactylifera is considered the most important plant grown in arid regions. This palm species suffers from a great disease problem caused by Fusarium oxysporum, which produces high economic losses in palm groves (Oihabi, 1991). The development of biological control against plant diseases is accepted nowadays as a durable and environmentally-friendly alternative for agrochemicals. Therefore, considerable attention is being paid to the isolation of fungal antagonists that could be as effective as pesticides in the repression of fungal pathogens (Benhamou and Chet, 1996). The mechanism responsible for biocontrol is unknown, although both hydrolytic enzymes (chitinases, glucanases and proteases) and naturally produced antibiotics play an important role.

Association of biocontrol agents such as T. harzianum and promoting microorganisms, such as arbuscular mycorrhiza fungi, may contribute to a better protection of the host plant.

* Corresponding author: azizabenkhaled@ hotmail.com
Arbuscular mycorrhizal fungi are obligate symbionts that live in association with the roots of most land plants. These fungi grow from the roots into the surrounding soil, forming an external hyphal network, which increases uptake of mineral immobile nutrients (Pedreno et al., 1997; Smith and Read, 1997). In addition, arbuscular mycorrhizal fungi promote plant growth and may contribute to the protection of the host plant against soilborne plant pathogens (Pozo et al., 2002). On the other hand, several Trichoderma strains have been reported to be effective in controlling plant diseases (Viterbo et al., 2002). Thus, combinations of arbuscular mycorrhizal fungi and biocontrol agents such as Trichoderma could provide levels of disease control which are superior to the effects of the organism when they are used alone (Lindermann, 1988; Datnoff et al., 1995). However, different authors have reported the suppression of arbuscular mycorrhizal root colonization by biocontrol Trichoderma species (Calvet, 1989; McAllister et al., 1994), although this effect may depend on the host plant species (Dhillion, 1994) and the timing of inoculation (McAllister et al., 1994). In addition, adverse effects 
of arbuscular mycorrhizal fungi on the population density of Trichoderma sp. have also been observed (Green et al., 1999). This type of study has never been carried out on date palms.

Although little is known about the biochemical and physiological processes occurring during the symbiosis establishment, some studies suggest that increased resistance of arbuscular mycorrhizal roots to pathogens may be associated in part with marked metabolic changes in the host, including an enhanced production of peroxidases and phenolic compounds (Spanu and Bonafante-Fasolo, 1988). Peroxidases (EC 1.11.1.7) oxidize a variety of phenolic compounds and have been implicated in many different physiological processes such as incorporation of phenolics into the cell wall, lignification and wound healing, and pathogen defense (Jaizme-Vega and Díaz-Pérez, 1991). An increase in peroxidase activity after inoculation of different plants with pathogenic fungi has been reported by different groups (Münzenberger et al., 1997; Salzer and Hager, 1993). It has been proposed that one role of plant peroxidases is to prevent spreading of pathogens by increasing cell wall rigidity through the incorporation of phenolics (Yedidia et al., 1999). The question arises whether fungal symbionts and saprophytic fungi influence peroxidase activities and isoenzyme patterns in plants in a manner similar to that induced by pathogens (Spanu and Bonafante-Fasolo, 1988). In the present study peroxidase activity was analyzed both in roots and leaves of $P$. dactylifera plantlets inoculated with G. mosseae and T. harzianum T22.

\section{MATERIALS AND METHODS}

\subsection{Fungi, plants and soil}

Palm seeds (Phoenix dactylifera) were obtained from Huerto del Cura station (Elche, Spain). The Glomus mosseae used as the arbuscular mycorrhiza fungi was multiplied with Sorghum bicolor $\times$ sudenense in pot cultures after 4 months of plant growth. Soil, spores and roots of the hybrid sorghum cultures were used as a crude inoculum for the Palm seedlings. $T$. harzianum $\mathrm{T}_{22}$ was supplied by "Koppert Biological Systems" (Murcia, Spain), and it was used in suspension at $1 \mathrm{~g} / \mathrm{L} / \mathrm{plant}$ concentration. The soil growth medium was a peat; this substrate was sterilized to eliminate indigenous pathogens.

\subsection{Germination and growth conditions}

Palm seeds were germinated in compartmented growth units of polyvinyl chloride tubes. The substrate was enriched with (15/9/15) NPK and $2 \mathrm{mg}$ of Floranid Permanent. The seedlings were transplanted into pots containing the same substrate, and grown in field conditions. After 2 months, the inoculum ( $5 \mathrm{~g}$ of root and $20 \mathrm{~g}$ of spore and mycelium inoculum G. mosseae) was added to the seedlings close to the root system. After 16 months, a group of plants was irrigated three times in 1 week with $T$. harzianum $\mathrm{T}_{22}$. Every week, $20 \mathrm{~mL}$ of the nutritive solution of Long Ashton was added to each seedling's pot.
Four treatments were used in this experiment: noninoculated controls, plants inoculated with G. mosseae, plants inoculated with T. harzianum and plants inoculated with both fungi. For these latter, plants were first inoculated with $G$. mosseae for 16 months, then with Trichoderma, in order to avoid the effect of Trichoderma on arbuscular mycorrhizal root colonization (Siddiqui and Mohmood, 1996).

\subsection{Protein extraction}

Leaves and young roots were separated, washed under running tap water three times and finally with distilled water, and dried gently. Plant material was homogenized for $2 \mathrm{~min}$ at $4{ }^{\circ} \mathrm{C}$ in a ratio of $1: 12(\mathrm{w} / \mathrm{v})$ in $0.1 \mathrm{M}$ sodium phosphate buffer ( $\mathrm{pH}$ 7.0) containing 20\% (w/v) polyvinylpyrrolidone. Palm leaves were homogenized with the same buffer without polyvinylpyrrolidone. The homogenate was centrifuged at $37000 \mathrm{~g}$ for $20 \mathrm{~min}$ at $+4{ }^{\circ} \mathrm{C}$ and the supernatant was used for enzyme assay. Protein contents were determined according to the method of Bradford (1976) using bovine serum albumin as the standard.

\subsection{Determination of soluble peroxidase activities}

Soluble peroxidase activity was determined spectrophotometrically in $1.7 \mathrm{~mL}$ reaction mixture containing $660 \mu \mathrm{L}$ of guaiacol $12 \mathrm{mM}, 50 \mu \mathrm{L}$ of $\mathrm{H}_{2} \mathrm{O}_{2} 8 \mathrm{mM}$ and $330 \mu \mathrm{L}$ of sodium acetate buffer $0.2 \mathrm{M}$ ( $\mathrm{pH}$ 5.0) by following the increase in the absorbance at $470 \mathrm{~nm}$ and using $\varepsilon_{470}=5200 \mathrm{M}^{-1} \mathrm{~cm}^{-1}$. One unit of activity (U) was defined as the amount of peroxidase oxidating $1 \mu$ mole of substrate/min at a temperature and $\mathrm{pH}$ specified for each reaction (Goldberg et al., 1983). Five enzymatic assays were carried out for each treatment.

\subsection{Electrophoresis}

The protein extracts were bought to $60 \%$ saturation with solid ammonium sulfate $\left(\mathrm{NH}_{4}\right)_{2} \mathrm{SO}_{4}$ under continuous stirring at $4{ }^{\circ} \mathrm{C}$. After $1 \mathrm{~h}$, the solution was centrifuged at $4{ }^{\circ} \mathrm{C}$ for $20 \mathrm{~min}$ at $120000 \mathrm{~g}$, then the pellets were resuspended in a small volume of $0.1 \mathrm{M}$ sodium phosphate buffer ( $\mathrm{pH}$ 5.0). The crude extracts were dialyzed overnight against the same buffer (sodium acetate $\mathrm{pH} 5.0$ ) at $4{ }^{\circ} \mathrm{C}$.

$20 \mu \mathrm{L}$ of each extract $(0.02 \mathrm{mg}$ of protein $)$ were subjected to Sodium dodecyl sulfate polyacrylamide gel electrophoresis (SDS-PAGE) with the presence of 2-mercaptoethanol of the ammonium sulfate. The pellet was on $12 \%$ acrylamide gel, according to the method of Laemmli (1970). Gels were internally calibrated using a high-molecular-mass marker kit (SigmaI) containing myosine $(205 \mathrm{KDa}), \beta$ galactosidase $(116 \mathrm{KDa})$, phospholipase b (97.4 KDa), bovine albumin (66 KDa), egg albumin $(45 \mathrm{KDa})$ and carbonic anhydrase $(29 \mathrm{KDa})$. The gels were stained for protein visualization with Coomassie Brilliant Blue.

Non-denaturing polyacrylamide gel electrophoresis (PAGE) was carried out at $4{ }^{\circ} \mathrm{C}$ on $10 \%$ acrylamide gels: both 
the resolving and the stacking gels were prepared with Tris$\mathrm{HCl}$ buffer $\mathrm{pH}$ 6.8. After the electrophoresis run, the gels were incubated for $60 \mathrm{~min}$ in $15 \mathrm{mM}$ sodium acetate buffer containing $8 \mathrm{mM} \mathrm{H}_{2} \mathrm{O}_{2}$ and $0.4 \mathrm{M}$ guaiacol. All electrophoresis was carried out in a mini-Protein cell (Bio-Rad).

\section{Cationic electrophoresis}

The extracts were mixed (v/v) with a buffer solution (3.1 mL staking buffer, $5 \mathrm{~mL}$ glycerol, $0.5 \mathrm{~mL}$ methyl green $(0.04 \%)$ and $1.4 \mathrm{~mL}$ distilled water). $20 \mu \mathrm{L}$ of each was separated in $35 \mathrm{M} \beta$-alanin buffer $\mathrm{pH} 4.5$. Discontinuous, nondenaturating acrylamide gel electrophoresis was prepared with $4 \%$ resolving gel (staking buffer $\mathrm{pH} 6.8$, ammonium persulfate $10 \%$, acrylamide $30 \%$, TEMED and water) and $10 \%$ separating gel (separating buffer $\mathrm{pH} 4.3$, ammonium persulfate $10 \%$, acrylamide $30 \%$, TEMED and water). Gels were soaked for 30 to $60 \mathrm{~min}$ in $15 \mathrm{mM}$ sodium acetate buffer $\mathrm{pH}$ 5, containing $8 \mathrm{mM} \mathrm{H}_{2} \mathrm{O}_{2}$ and $0.4 \mathrm{M}$ guaiacol, for staining.

\subsection{Visual quantification of root colonization}

The root samples from the treatments with G. mosseae and G. mosseae + T. harzianum were cleared in a $\mathrm{KOH}(10 \%)$ solution and stained with Trypan Blue according to Phillips and Hayman (1970) using lactoglycerol. Mycorrhizal colonization was determined by the method of Trouvelot et al. (1986). An average of 150 root pieces per plant and 5 plants per treatment were examined. The results are given as percents of the root lengths infected. The presence of the mycelium of Trichoderma attached to the surface of the roots was checked visually under a magnifying glass.

\subsection{Transmission electron microscopy and cytochemical peroxidase localization}

Root and leaf samples were collected 16 months after inoculation with $G$. mosseae and 21 days after inoculation with Trichoderma, rinsed with distilled water, then cut into small pieces $(1-2 \mathrm{~cm})$ and immersed in $1.25 \%(\mathrm{v} / \mathrm{v})$ glutaraldehyde in $0.1 \mathrm{M}$ phosphate buffer (pH:7.3) for $1 \mathrm{~h}$ at $4{ }^{\circ} \mathrm{C}$. Samples were incubated in 3,3-diaminobenzidine, $\mathrm{H}_{2} \mathrm{O}_{2}$ as substrates and 3-Amino-1,2,4-triazole inhibitor of catalase in Tris- $\mathrm{HCl}$ buffer (pH:7.6) for $30 \mathrm{~min}$ in the dark. After that, samples were washed twice for $5 \mathrm{~min}$ in Tris-HCl buffer (pH: 7.6) and postfixed in $1 \%(\mathrm{w} / \mathrm{v})$ osmium tetroxide in the same buffer for 30 min, dehydrated in a graded ethanol series, and embedded in Epon-araldite resin and polymerized at $60{ }^{\circ} \mathrm{C}$ for $48 \mathrm{~h}$.

Ultrathin sections $(90 \mu \mathrm{m})$ were cut with a diamond knife and collected on formvar-coated nickel grids. The sections were treated with uranyl acetate and lead citrate before observations in the transmission electron microscope. For each treatment, an average of five samples from four different leaves and roots were investigated. For each sample, 5 to 10 ultrathin sections were examined.
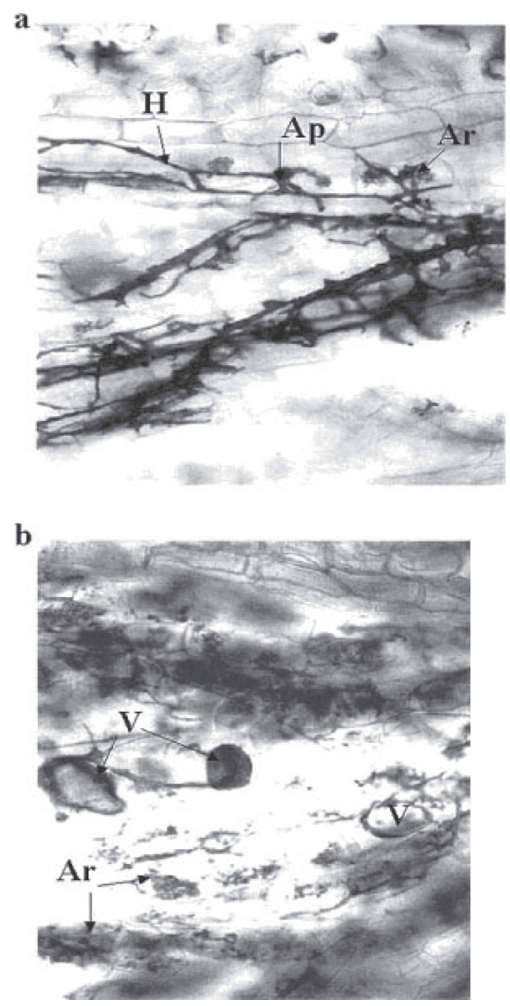

Figure 1. Root of date palm stained with trypan blue that is extensively colonised by Glomus mosseae. a and $\mathbf{b}$ : infection began by formation the appressorium (Ap), a dense group of hyphal within the cortex, intracellular fungal hyphae penetrate a root and differentiate to form arbuscules (Ar) and vesicles in cortex cells (V). The magnification of the panels (a and $\mathbf{b}$ ) is $\times 200$.

\subsection{Statistical analysis}

Significances between means were tested by two tests: Duncan's multiple range test $(P=0.05)$ and the NewmanKeuls test $(P=0.05)$. Five replications were pooled.

\section{RESULTS AND DISCUSSION}

\subsection{Arbuscular mycorrhizal colonization}

At harvest, 57 weeks after mycorrhization, G. mosseae allowed an improvement of the dry biomass of about $57 \%$. The typical arbuscular mycorrhizal structures such as vesicles, arbuscules and intraradical mycelium were observed in the mycorrhizal plants (Fig. 1). The percentage of mycorrhizal colonization at harvest time varied between 25 and $30 \%$ and no mycorrhizal infection was found in control plants. This percentage of colonization was very similar to those obtained for other palm species (Jaizme-Vega and Díaz-Pérez, 1991; Morte and Honrubia, 2002). The mycorrhizae infection may introduce metabolic modifications. As far as the enzymes are proteins, any metabolic changes may affect the total protein contents. 


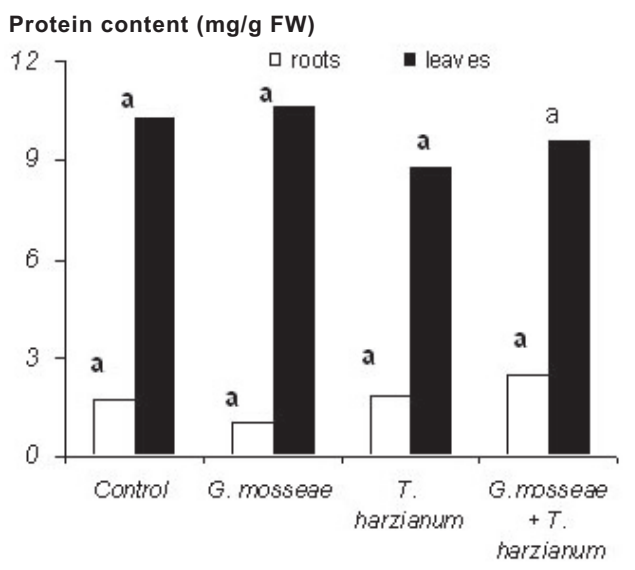

Treatments

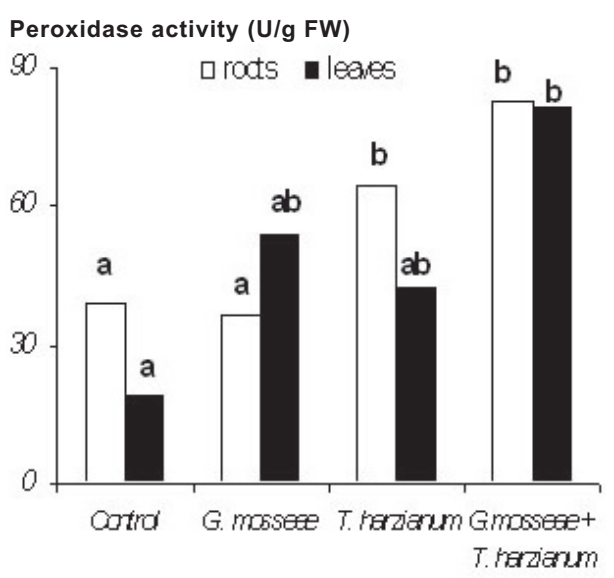

Treatments
Figure 2. Protein content in roots ( $\square$ ) and leaves ( $\mathbf{a})$ of noninoculated (control), inoculated with G. mosseae (Gm), T. harzianum (Th), or with both $G$. mosseae and $T$. harzianum $(\mathrm{Gm}+\mathrm{Th}) P$. dactylifera plants. Plants were inoculated and grown under greenhouse conditions for 16 months with $G$. mosseae and then irrigated three times with a Trichoderma harzianum T22 (Koppert Biology systems) solution ( $1 \mathrm{~g} \mathrm{~L}^{-1}$ per plant). The substrate used was a mixture of peat and vermiculite. Significances between means were tested by two tests: Duncan's multiple range test $(P=0.05)$. Five replications were pooled. Results with a similar letter are considered non significatives.

\subsection{Protein content}

The protein content in leaves was not affected by the inoculation with T. harzianum and/or G. mosseae, but roots of plants inoculated with G. mosseae presented a protein content significantly lower than the leaves. In general, the protein content in leaves was 4 to 10 times higher than in roots (Fig. 2).

\subsection{Peroxidase activity}

In control plants, peroxidase activity (expressed as U/g FW) was $15 \mathrm{U} / \mathrm{g} \mathrm{FW}$, and this value was approximately 2.5 times higher in roots than in leaves (Fig. 3) and significantly lower than the activity measured in date palm and other palm species by Sakharov et al. (2001). The peroxidase activity is completely absent in the leaves of the Madagascar palm (Chrysalidocarpus lutescens), and it was only $50 \mathrm{U} / \mathrm{g}$ of leaf in leaves of the coconut palm (Cocos nucifera) (Sakharov et al., 2001). This author added that the highest peroxidase activity was detected in leaves of ruffle palm (Aiphanes cariotifolia), royal palm ( $R$. regia), date palm (Phoenix dactylifera) and African oil palm (Elaeis guineensis) with activities of 1150, 700, 580 and $570 \mathrm{U}$ per g leaves, respectively.

Peroxidase activity was higher in roots colonized by $T$. harzianum alone or in combination with $G$. mosseae than in noninoculated control plants (Fig. 3). No significant difference in peroxidase activity was observed between noninoculated control plants and plants colonized by G. mosseae, indicating that most of the activity was derived from the $T$. harzianum. A similar result was reported by Yedidia et al. (1999), who observed that the inoculation of Cucumber plants with Trichoderma increases peroxidase and chitinase activities
Figure 3. Peroxidase activity in roots ( $\square$ ) and leaves ( $\square$ ) of noninoculated (control), inoculated with G. mosseae $(\mathrm{Gm}), T$. harzianum (Th), or with both $G$. mosseae and T. harzianum $(\mathrm{Gm}+\mathrm{Th}) P$. dactylifera inoculated. Soluble peroxidase activity was determined spectrophotometrically by following the increase in absorbance at $470 \mathrm{~nm}$ and using $\varepsilon_{470}=5.200 \mathrm{M}^{-1} \mathrm{~cm}^{-1}$. Significances between means were tested by two tests: Duncan's multiple range test $(P=$ $0.05)$. Five replications were pooled. Results with a similar letter are considered non significatives.

both in roots and leaves. The delay between plant inoculation with G. mosseae and the determination of peroxidase activities (16 months and three weeks) could explain the fact that the measured peroxidase activities showed similar values compared with the control plants. Spanu and Bonfante-Fasolo (1988) observed that higher cell wall peroxidase activities occur at the beginning of symbiotic establishment of Glomus versiforme in garlic plants; at more advanced stages these activities decreased to the same level as in nonmycorrhizal plants. Transient increases in peroxidase activity have also been detected in root cell walls of Allium porrum during early stages (16 days) of colonization with the vesicular-arbuscular mycorrhizal fungus $G$. versiforme; after that (50 days), there was a decrease in activity which reached the same level as that of noncolonized plants (Spanu and Bonafante-Fasolo, 1988). Mycorrhizal fungi increased peroxidase and polyphenoloxidase activities in Ziziphus. xylopyrus roots (Mathur and Vyas, 1996). The increased peroxidase activity by mycorrhizal fungi may be due to an increased $\mathrm{P}$ uptake resultant from the symbiosis. McArthur and Knowles (1992) reported a positive correlation between root phosphorus uptake and peroxidase activity.

Since the "infection development stage" may influence the level of peroxidase, the observed increase in peroxidase activity may likely be attributed to the Trichoderma infection rather than the mycorrhizal establishment. On the other hand, Salzer and Hager (1993) described the suppression of the elicitor induction of peroxidase by auxins. As many mycorrhizal fungi produce auxin (Münzenberger et al., 1997), it is conceivable that peroxidase activity is suppressed by fungal auxin in the intact system. The long time needed (at least three months) to get a good development of mycorrhizal infection 


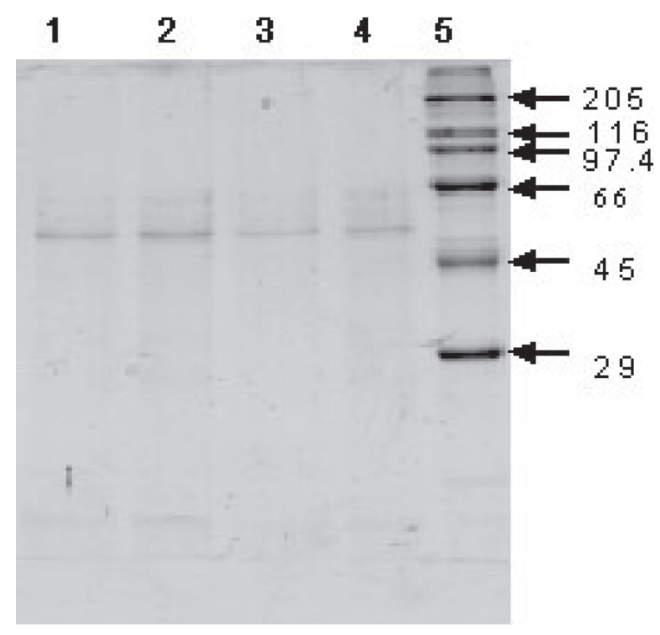

Figure 4. SDS-PAGE of palm leaf extracts: (1) $20 \mu \mathrm{L}$ of plants inoculated with $G$. mosseae; (2) $20 \mu \mathrm{L}$ of plants inoculated with $T$. harzianum; (3) $20 \mu \mathrm{L}$ of control noninoculated plants; (4) $15 \mu \mathrm{L}$ of plants inoculated with G. mosseae and T. harzianum T22; (5) $10 \mu \mathrm{L}$ of molecular markers. Gels were internally calibrated using a highmolecular-mass marker kit (Sigma SDS-6H) containing: myosine (205 kDa); $\beta$-galactosidase (116 kDa); phospholipase b (97.4 kDa); bovine albumine ( $66 \mathrm{kDa})$; albumine egg $(45 \mathrm{kDa})$ and carbonic anhydrase $(29 \mathrm{kDa})$. The gels were stained for protein visualization with Coomassie Brilliant Blue.

in Phoenix species (Morte and Honrubia, 2002; Yedidia et al., 1999; Dreyer et al., 2001) makes the measurement of the levels of peroxidase activity difficult at the early stages of mycorrhizal colonization.

In leaves, significant differences were observed only between noninoculated control plants and plants colonized by both fungi (Fig. 3). This increase suggests the existence of a signal that is transported from the infection sites throughout the whole plant, inducing the synthesis of defensive enzymes such as peroxidase. A similar response has been described in tomato (Bergey et al., 1996). To approach the overall metabolic modifications a separation of the native total protein is fulfilled.

\subsection{Electrophoresis method}

The SDS-PAGE analyses of palm leaf extracts gave a main band at $54 \mathrm{kDa}$ for all the treatments (Fig. 4). This band could correspond to the peroxidase, as the estimated molecular mass is comparable with that found by Sakharov et al. (2000) for P. dactylifera peroxidase. However, further purification is necessary to ascertain that this band corresponds to peroxidase. Using native cationic electrophoresis, several basic peroxidase isoenzymes were detected in roots for all fungal treatments and control (Fig. 5). The electrophoretic pattern was different in control plants with respect to fungal inoculated plants. When native anionic electrophoresis was carried out at $\mathrm{pH}$ 6.6, two bands corresponding to acid peroxidase isoenzymes were observed in roots of T. harzianum-infected plants and G. mosseae-colonized plants. One of these bands was not present in plants inoculated with both T. harzianum

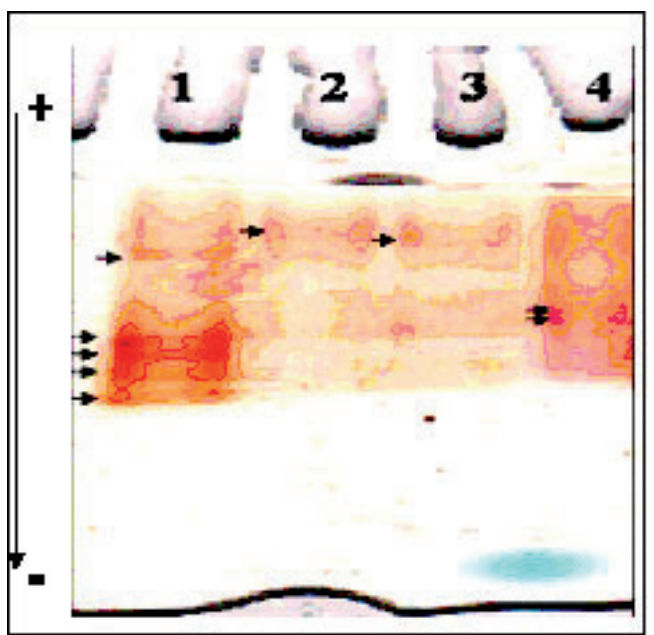

Figure 5. Native cationic electrophoresis in roots of palm extracts (1) control (2) plants inoculated with G. mosseae; (3) plants inoculated with $T$. harzianum T22; (4) plants inoculated with G. mosseae and T. harzianum T22. Peroxidase was visualized following the method described by Reisfeld and co-workers and modified by Escribano et al.

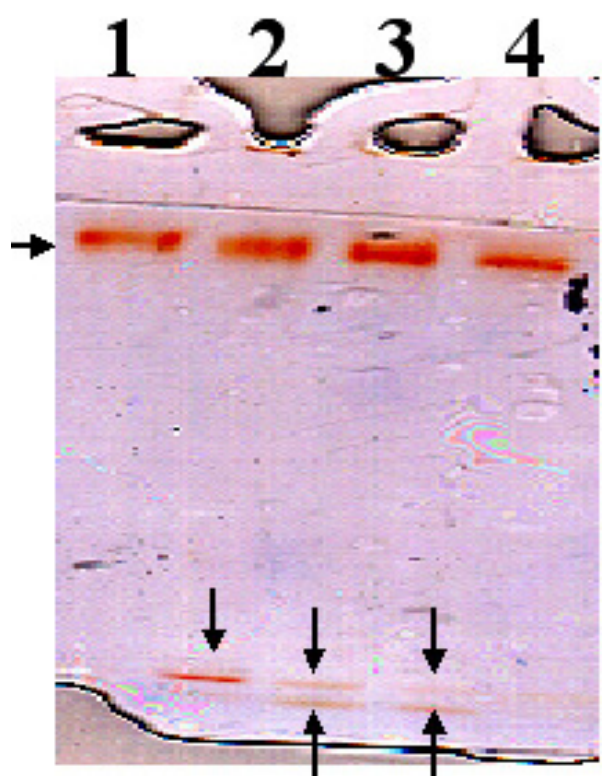

Figure 6. Native anionic electrophoresis in roots of palm extracts (1) Control (2) plants inoculated with G. mosseae and T. harzianum T22; (3) plants inoculated with T. harzianum T22; (4) plants inoculated with $G$. mosseae. The band corresponding to acid peroxidase isoenzymes is absent in plants control.

and G. mosseae and both of them were absent in control plants (Fig. 6). More experiments have to be carried out to clarify these results.

\subsection{Histochemical studies}

T. harzianum T22 penetrated into the epidermical root cells. The T. harzianum hyphae were characterized by a high 

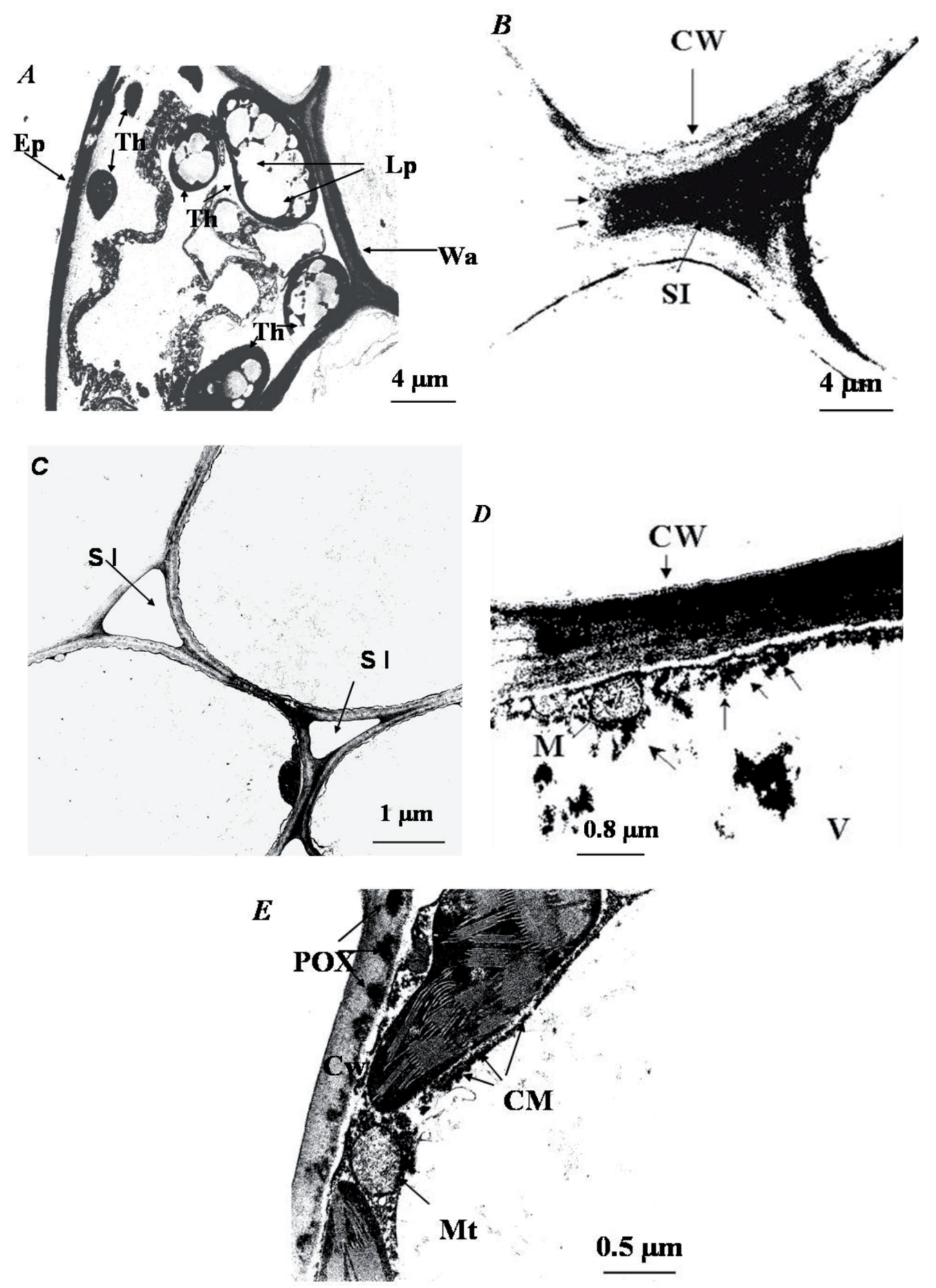

Figure 7. (A) Epidermal root cell of P. dactylifera colonized by T. harzianum hyphae (Th), lipid vesicles (Lp), wall appositions (Wa); (B, D) Cortical root cell of $P$. dactylifera palms inoculated with both $T$. harzianum and $G$. mosseae fungi: electron-dense deposits indicated a peroxidase activity. These were observed on the internal side of the cell walls (CW), at the intercellular spaces (IS) and vacuole (V); (C) Cortical root cell of $P$. dactylifera control without peroxidase activity at the intercellular spaces (IS); (E) Leaf cell of $P$. dactylifera palms inoculated with both T. harzianum and G. mosseae: peroxidase activity (POX) was found in the cell walls $(\mathrm{CW})$, mitochondria membrane (Mt) and cytoplasm membrane $(\mathrm{T})$. 
electron density of their cytoplasm and numerous lipid vesicles (Fig. 7A). The formation of heterogeneous wall appositions was observed in the noninfected host cell adjacent to infected cells. They were elongated deposits along a large portion of the host cell wall (Fig. 7A). A similar observation was reported by Yedidia et al. (1999) with cucumber roots infected by Trichoderma harzianum T22. It was suggested that host cells produce signals to mobilize defense strategies such as the accumulation of heterogeneous wall appositions, and this dense material originated from an aggregation of the host cytoplasm, or was newly synthesized as a response to infection (Yedidia et al., 1999).

Peroxidases are normally present in roots, leaves and stems of plants. These enzymes can be found in vacuoles (Pedreño et al., 1993), the apoplast (Takahama and Oniki, 1992), the plasmalemma, and inside and outside the cell wall (Pedreño et al., 1995; Mäder, 1992). In Phoenix dactylifera peroxidase activity was observed on the internal side of the cell walls, and in the intercellular spaces (Fig. 7B) and the vacuole of palm root inoculated with both fungi, G. mosseae and T. harzianum (Fig. 7C). In the leaves of the same treatment peroxidase was localized in the cell wall, the host plasmalemma, the tonoplast and the chloroplast membrane (Fig. 7D).

\section{CONCLUSION}

Mycorrhization allowed an improvement of the dry biomass. Quantitative and qualitative peroxidase study showed significant differences between controls and plants inoculated with Trichoderma harzianum T22 alone or combined with Glomus mosseae. The inoculation with Trichoderma on already mycorrhized palm date seedlings seems to induce a high peroxidase activity in leaves and roots. Peroxidase cytochemical localization was established in the intercellular regions, cell walls, cytoplasm and in chloroplastic and mitochondrial membranes. The stimulatory effect of Trichoderma on peroxidase activity production could be one of many resistance mechanisms of plants to pathogens. The combination of mycorrhiza and Trichoderma showed synergetic effects.

Acknowledgements: This work has been partially supported by the Ministerio de Asuntos Exteriores, A.E.C.I., Programa de Cooperación Interuniversitaria Hispano-Marroquí, Project Ref. 1PRO/00 and Project BMC2001-0499 (MCyT, Spain). MPG holds a contract from the program "Ramón y Cajal" (MCyT, Spain).

\section{REFERENCES}

Benhamou N., Chet I. (1996) Parasitism of sclerotia of Sclerotium rolfsii by Trichoderma harzianum: ultrastructural and cytochemical aspects of the interaction, Phytopathology 86, 405-416.

Bergey D.R., Howe G.A., Ryan C.A. (1996) Polypeptide signaling for plant defensive genes exhibits analogies to defense signaling in animals, Proc. Natl Acad. Sci. USA 93, 12053-12058.

Bradford M.M. (1976) A rapid and sensitive method for the quantitation of microgram quantities of protein utilizing the principal of proteindye binding, Annal. Biochem. 72, 248-254.
Calvet C., Pera J., Barea J.M. (1989) Interactions of Trichoderma spp. with Glomus mosseae and two wilt pathogenic fungi, Agr. Ecosyst. Environ. 29, 59-65.

Datnoff L.E., Nemec S., Pernezny K. (1995) Biological control of fusarium crown and root rot of tomato in Florida using Trichoderma harzianum and Glomus intraradices, Biol. Control 5, 427-431.

Dhillion S.S. (1994) Effect of Trichoderma harzianum, Beijerinckia mobilis and Aspergillus niger on arbuscular mycorrhizal infection and sporulation in maiza, wheat, millet, sorghum, barley and oats, J. Plant Dis. Prot. 101, 272-277.

Dreyer B., Morte A., Honrubia M. (2001) Growth of mycorrhizal Phoenix canariensis plants under three different cultivation systems. Plant nutrition: food security and sustainability of agro-ecosystems through basic and applied research. Fourteenth International Plant Nutrition Colloquium, Hannover, Germany, pp. 648-649.

Goldberg R., Catesson A.M., Czaninski Y. (1983) Some properties of syringaldazine oxidase, a peroxidase specifically involved in the lignification processes, Z. Pflanzenphysiol. 110, 267-279.

Green H., Larsen J., Olsson P.A., Jensen D.F., Jakobsen I. (1999) Suppression of the biocontrol agent Trichoderma harzianum by mycelium of the arbuscular mycorrhizal fungus Glomus intraradices in root-free soil, Appl. Environ. Microb. 65, 1428-1434.

Jaizme-Vega M.C., Díaz-Pérez M.A. (1991) Effect of Glomus intraradices on Phoenix robelini during the nursery stage, Proc. 2nd Int. Symp. On Ornamental Palms and Other Monocots from the Tropics, Acta Horticulturae 486, ISHS.

Laemmli U.K. (1970) Cleavage of structural proteins during the assembly of the head of bacteriophage $\mathrm{T}_{4}$, Nature 227, 680-685.

Lindermann R.G. (1988) Mycorrhizal interactions with the rhizosphere microflora: the mycorrhizosphere effect, Phytopathology 78, 366-371.

Mäder M. (1992) Compartmentation of peroxidase isoenzymes in plant cells, in: Penel C., Gaspar T., Greppin H. (Eds.), Plant Peroxidases 1980-1990, University of Geneva, Switzerland, pp. 37-46.

Mathur N., Vyas A. (1996) Biochimical changes in Ziziphus xylopyrus by VA mycorrhizae, Bot. Bull. Acad. Sinica 37, 209-212.

Mc Allister C.B., García-Romera I., Godeas A., Ocampo J.A. (1994) Interactions between Trichoderma koningii, Fusarium solani and Glomus mosseae: effects on plant growth, arbuscular mycorrhizas and the saprophyte inoculants, Soil Biochem. 26, 1363-1367.

Mc Arthur D.A., Knowles N.R. (1992) Resistance responses of potato to vesicular-arbuscular mycorrhizal fungi under varying abiotic phosphorus levels, Plant Physiol. 100, 341-351.

Morte A., Honrubia M. (2002) Growth response of Phoenix canariensis to inoculation with arbuscular mycorrhizal fungi, Palms 46, 76-80.

Münzenberger B., Otter T., Würstrich D., Polle A. (1997) Peroxidase and laccase activities in mycorrhizal and non-mycorrhizal fine roots of Norway spruce (Picea abies) and larch (Larix decidua), Can. J. Bot. 75, 932-938.

Oihabi A. (1991) Étude de l'influence des mycorhizes a vesicules et arbuscules sur le bayoud et la nutrition du palmier dattier, Doctoral Thesis, Université de Bourgogne, Dijon, France, pp. 39-45.

Pedreño M.A., Bernal M.A., Calderon A.A., Ferrer M.A., LopezSerrano M., Merino de Smith S.E., Read D.J. (1997) Mycorrhizal Symbiosis, Academic Press, London, pp. 1-605.

Pedreño M.A., Bernal M.A., Calderon A.A., Ferrer M.A., LopezSerrano M., Merino de Caceres F., Muñoz R., Ros Barcelo A. (1993) A general pattern for perxidase isoenzyme localization and function in vitaceae, solanaceae and leguminoseae, in: Welinder K.G., Rasmussen S.K., Penel C., Greppin H. (Eds.), Plant Peroxidases, Biochemistry and Physiology, RochatBaumann, Imprimerie Nationale, Geneva, pp. 307-314.

Pedreño M.A., Ferrer M.A., Gaspar T.H., Munoz R., Ros Barceló A. (1995) The polyfunctionality of cell wall peroxidases avoids the necessiry of an independent $\mathrm{H}_{2} \mathrm{O}_{2}$-generating system for phenolic coupling in the cell wall, Plant Perox. Newslett. 5, 3-8. 
Phillips J.M., Hayman D.S. (1970) Improved procedures for clearing roots and staining parasitic and vesicular-arbuscular mycorrhizal fungi for rapid assessment of infection, Trans. Brit. Mycol. Soc. $55,158-161$.

Pozo M.J., Cordier C., Dumas-Gaudot E., Gianinazzi S., Barea J.M., Azcón-Aguilar C. (2002) Localized versus systemic effect of arbuscular mycorrhizal fungi on defence responses to Phytophthora infection in tomato plants, J. Exp. Bot. 53, 525-534.

Sakharov I.Y., Castillo L.J., Areza J.C., Galaev I.Y. (2000) Purification and stability of peroxidase of African oil palm Elaies guineensis, Bioseparation 9, 125-132.

Sakharov I.Y., Vesga M.K., Galaev I.Y., Sakharova I.V., Pletjushkina O.Y. (2001) Peroxidase from leaves of royal palm tree Roystonea regia: purification and some properties, Plant Sci. 161, 853-860.

Salzer P., Hager A. (1993) Effect of auxins and ectomycorrhizal elicitors on wall-bound proteins and enzymes of spruce (Picea abies L. Karst), Trees 8, 49-55.

Siddiqui Z.A., Mohmood I. (1996) Biological control of Heterodera cajani and Fusarium udum on pigeonpea by Glomus mosseae, Trichoderma harzianum and Verticillium chlamydosporium, Isr. J. Plant Sci. 44, 49-56.
Smith S.E., Read D.J. (1997) Mycorrhizal symbiosis, Academic Press, London New York.

Spanu P., Bonafante-Fasolo P. (1988) Cell wall bound peroxidase activity in roots of mycorrhizal Allium porrum, New Phytology 109, 119124.

Takahama U., Oniki T. (1992) Regulation of peroxidase-dependent oxidation of phenolics in the apoplast of spinach leaves by ascorbate, Plant Cell Physiol. 33, 379-387.

Trouvelot A., Kough J.L., Gianinazzi-Pearson V. (1986) Mesure du taux de mycorhization VA d'un système radiculaire. Recherche de méthodes d'estimation ayant une signification fonctionnelle, in: Gianinazzi S. (Ed.), Les Mycorhizes : Physiologie et Génétique, 1er Séminaire Européen sur les Mycorhizes, Dijon, INRA, pp. 217221.

Viterbo A., Ramot O., Chemin L., Chet I. (2002) Significance of lytic enzymes from Trichoderma spp. in the biocontrol of fungal plant pathogens, Anton. Leeuw. Int. J. G. 81, 549-556.

Yedidia I.I., Benhamou N., Chet I.I. (1999) Induction of defense responses in cucumber plants (Cucumis sativus L.) by the biocontrol agent Trichoderma harzianum, Appl. Environ. Microb. 65, 1061-1070. 